\title{
KAJIAN KEBIJAKAN PENDIDIKAN DALAM UNDANG-UNDANG SISTEM PENDIDIKAN NASIONAL
}

\author{
Imam Rohani \\ Dosen Tetap Fak. Tarbiyah IAIRM Ngabar Ponorogo \\ Imamrohani100@gmail.com
}

\begin{abstract}
Abstrak:
Keberlangsungan pendidikan dalam sebuah Negara tidak terlepas dari kebijakan-kebijakan yang diterapkan oleh Pemerintah setempat. Persoalan utama dalam pembahasan ini adalah apa sajakah kebijakan-kebijakan pemerintah Indonesia di bidang pendidikan yang tertuang dalam Undang-undang Nomor 20 Tahun 2003 tentang Sistem Pendidikan Nasional dan peraturan perundangundangan yang menyertainya, dan menemukan apa saja yang muncul seiring dengan pemberlakuan Undang-Undang tersebut serta bagaimana solusi pemecahannya. Hasil pembahasan menunjukkan bahwa ada beberapa kebijakan pendidikan nasional yang ditetapkan oleh pemerintah Indonesia dalam kurun waktu 2003 hingga 2010. Kebijakan-kebijakan tersebut adalah: 1) Standar Nasional Pendidikan yang kemudian menetapkan delapan standar nasional; 2) Wajib belajar sembilan tahun yang sering dianggap masyarakat sebagai sekolah gratis; 3) Kurikulum Tingkat Satuan Pendidikan yang didasarkan pada Kurikulum Berbasis Kompetensi dan semangat otonomi daerah; 4) Pengelolaan pendidikan dalam bentuk Badan Hukum Pendidikan yang kemudian dibatalkan; 5) Pendanaan pendidikan; 6) Sertifikasi bagi guru dan dosen; dan 7) Kebijakan penataan dalam penyelenggaraan Pendidikan Agama dan Pendidikan Keagamaan. Permasalahan yang muncul seiring dengan pemberlakuan berbagai kebijakan nasional di bidang pendidikan di Indonesia juga cukup banyak. Berbagai pemecahan sudah ditempuh untuk menyelesaikan problem-problem tersebut. Karena perbedaan situasi dan kondisi di masing-masing daerah tempat pelaksanaan berbagai kebijakan pendidikan, maka masih banyak problem yang belum teratasi dengan tuntas dan masih terus diupayakan.
\end{abstract}

Kata Kunci: Kebijakan pendidikan, Undang-undang, Sistem Pendidikan Nasional

\section{Pendahuluan}

Ada dua hal pokok di dalam Undang-Undang Dasar 1945 yang terkait dengan pendidikan nasional, yaitu: pendidikan adalah hak bagi seluruh rakyat Indonesia dan pendidikan mempunyai tujuan untuk mencerdaskan kehidupan bangsa. Pendidikan yang mencerdaskan ini, tidak hanya bertujuan untuk menjadikan bangsa Indonesia sebagai bangsa kelas dua dalam dunia modern atau 
menjadi pekerja-pekerja dari industri-industri besar yang dibiayai oleh modal asing, tetapi bangsa yang cerdas adalah bangsa yang berdiri sendiri (Tilaar, 2009).

Assegaf menambahkan bahwa terjadinya perubahan kebijakan pendidikan nasional bisa dikaji melalui upaya analisis kebijakan, yakni analisis yang membuat generalisasi atau menyajikan informasi sedemikian rupa hingga dapat memperbaiki dasar bagi para perumus kebijakan untuk mengevaluasi keputusan mereka (Assegaf, 2005). Analisis kebijakan ini bertujuan untuk kepentingan pembaruan pendidikan, setelah diketahui faktor keberhasilan dan kendala selama kebijakan pendidikan nasional dilaksanakan.

Dalam pembahasan ini, kebijakan-kebijakan pendidikan nasional yang sekaligus menjadi politik pendidikan nasional yang dianalisis dibatasi waktunya, yakni pada kurun waktu tujuh tahun, mulai 2003 hingga 2010. Tahun 2003 menjadi tahun penting untuk pembatasan ini, mengingat pada tahun inilah keluar Undang-Undang No. 20 tahun 2003 yang secara khusus mengatur sistem pendidikan nasional Indonesia yang merupakan penyempurnaan dari undangundang tentang perihal yang sama pada tahun 1989 (UU No. 2/1989). Dalam kurun waktu tujuh tahun (2003-2010) telah muncul berbagai kebijakan nasional tentang pendidikan yang dituangkan dalam berbagai produk perundang-undangan nasional tentang pendidikan, mulai dari undang-undang, peraturan pemerintah, peraturan menteri pendidikan nasional, dan keputusan menteri pendidikan nasional.

Melalui berbagai produk perundang-undangan pendidikan ini dapat dianalisis berbagai kebijakan nasional terkait dengan pendidikan di Indonesia dalam berbagai aspek atau bidang kebijakan yang muncul serta latar belakang yang mengiringi munculnya kebijakan-kebijakan tersebut. Di antara kebijakankebijakan pemerintah Indonesia dalam masalah pendidikan yang sangat menonjol adalah di-launching-nya kurikulum baru yang diberi nama kurikulum berbasis kompetensi (KBK) tahun 2004 yang sebenarnya sudah didahului dengan pemberlakuannya di beberapa sekolah, SMK dan SMA mulai tahun 2002 serta SMP mulai tahun 2003. Dalam perkembangan selanjutnya KBK ini diteruskan dengan kurikulum tingkat satuan pendidikan atau sering dikenal dengan KTSP 
(2006) yang masih berjalan hingga sekarang. KTSP ini muncul sebagai konsekuensi dari adanya proses desentralisasi pendidikan yang beriringan dengan perjalanan proses otonomi daerah.

Kebijakan lain yang juga sangat menonjol adalah ditetapkannya standar pendidikan nasional yang dimulai dengan keluarnya Peraturan Pemerintah No. 19 tahun 2005 tentang Standar Nasional Pendidikan (SNP). Bersamaan dengan ini, pemerintah Indonesia juga membentuk badan independen yang dinamai Badan Standar Nasional Pendidikan (BSNP). Badan inilah yang kemudian bertanggung jawab merencanakan dan mengawal terwujudnya standar-standar pendidikan nasional. Itulah dua kebijakan yang menonjol dalam system pendidikan nasional yang hingga sekarang masih terus diupayakan pemberlakuannya ke seluruh wilayah nusantara.

Tentu saja masih banyak lagi kebijakan pemerintah Indonesia dalam bidang pendidikan yang sekaligus menjadi bagian dari politik pendidikan nasional di samping dua kebijakan tersebut.Kebijakan-kebijakan pemerintah dalam bidang pendidikan seperti di atas muncul didasari oleh berbagai permasalahan yang muncul seiring dengan perkembangan politik nasional. Masalah pokok dalam pembahasan ini adalah apa sajakah kebijakan-kebijakan pemerintah Indonesia di bidang pendidikan dalam kurun waktu 2003-2010 dan sejauh manakah kebijakankebijakan itu memberikan sumbangan dalam membangun perpolitikan nasional Indonesia di bidang pendidikan serta permasalahan apa sajakah yang muncul seiring dengan pemberlakuan kebijakan-kebijakan pemerintah di bidang pendidikan dalam kurun waktu 2003-2010 dan bagaimana pemecahannya.

Salah satu tujuan pendirian negara dan bangsa Indonesia adalah mencerdaskan kehidupan bangsa. Inilah cita-cita politik yang dirumuskan oleh pendiri bangsa seperti tercantum dalam Pembukaan Undang-Undang Dasar 1945. Dalam konteks politik, pendidikan telah menjadi bahan jualan politik dalam rangka meraih simpati serta dukungan suara. Setiap momen kampanye baik pada skala nasional maupun lokal hampir selalu menawarkan program terkait dengan pendidikan, misalnya program tidak bisa dilepaskan dari kebijakan-kebijakan yang muncul dalam bidang pendidikan di negara kita. 


\section{Pembahasan}

Untuk mengurai kebijakan pemerintah Indonesia di bidang pendidikan yang sekaligus menjadi politik pendidikan Indonesia akan diungkap salah satu undangundang yang berisi sistem pendidikan nasional, yaitu Undang-Undang Nomor 20 Tahun 2003, juga akan disinggung sumber perundang-undangan penting tentang pendidikan yang lain baik berupa Undang-Undang, Peraturan Pemerintah, maupun Peraturan Menteri Pendidikan Nasional.

\section{Undang-undang tentang Pendidikan sebagai Kebijakan Nasional dalam}

\section{Bidang Pendidikan}

Kajian ini tidak berpretensi untuk membahas seluruh perundang-undangan pendidikan yang ada di Indonesia, tetapi akan dibatasi mulai tahun 2003 ketika keluar Undang-Undang Nomer 20 Tahun 2003 tentang Sistem Pendidikan Nasional (UU Sisdiknas). Kajian ini difokuskan pada Undang-Undang No. 20 Tahun 2003 tentang Sistem Pendidikan Nasional yang berisi hal-hal pokok dan mendasar tentang sistem pendidikan di Indonesia sekaligus memuat aturan-aturan tentang kebijakan pendidikan di Indonesia.

Undang-undang Sisdiknas 2003 tersebut sebenarnya merupakan kelanjutan dari undang-undang sebelumnya, yaitu Undang-Undang Nomor 2 Tahun 1989 tentang Sistem Pendidikan Nasional. Kehadiran UU No. 2 Th. 1989 (selanjutnya disebut UU Sisdiknas 1989) ini sangat ditunggu oleh masyarakat yang memiliki kepedulian tentang pendidikan di Indonesia, mengingat UU yang lahir sebelumnya belum mengatur masalah pendidikan secara komprehensif. Kehadiran UU Sisdiknas 1989 menegaskan bahwa penyelenggaraan pendidikan di Indonesia merupakan suatu sistem.

Penyelenggaraan sistem pendidikan ini bertujuan untuk memantapkan ketahanan nasional dan mewujudkan masyarakat maju yang berakar pada kebudayaan bangsa serta persatuan nasional yang berwawasan Bhinneka Tungga Ika berdasarkan Pancasila dan Undang-Undang Dasar 1945. Kelahiran UU Sisdiknas 1989 ini secara lebih mendasar dilatarbelakangi juga oleh kehendak untuk mewujudkan UUD 1945 sebagai hukum dasar yang mengamanatkan bahwa kemerdekaan bertujuan untuk mencerdaskan kehidupan bangsa. Amanat ini 
langsung menyentuh tanggung jawab pemerintah Indonesia agar mengupayakan dan menyelenggarakan satu sistem pendidikan nasional yang diatur dengan undang-undang.

Isi UU Sisdiknas 2003 secara keseluruhan terdiri dari 22 bab dan 77 pasal. Bab I memuat ketentuan umum yang berisi satu pasal yang berisi penjelasan tiga puluh kata kunci yang digunakan dalam UU Sisdiknas 2003. Bab II mengenai Dasar, Fungsi, dan Tujuan yang berisi dua pasal, yakni pasal 2 dan 3. Pasal 2 menyatakan bahwa pendidikan nasional berdasarkan Pancasila dan UUD 1945, sedang pasal 3 menegaskan fungsi dan tujuan pendidikan, yakni pendidikan nasional berfungsi mengembangkan kemampuan dan membentuk watak serta peradaban bangsa yang bermartabat dalam rangka mencerdaskan kehidupan bangsa, bertujuan untuk berkembangnya potensi peserta didik agar menjadi manusia yang beriman dan bertakwa kepada Tuhan Yang Maha Esa, berakhlak mulia, sehat, berilmu, cakap, kreatif, mandiri, dan menjadi warga negara yang demokratis serta bertanggung jawab.

Bab III berisi tentang Prinsip Penyelenggaraan Pendidikan yang hanya memuat satu pasal, yakni pasal 4. Pada pasal ini ditetapkan enam prinsip penyelenggaraan pendidikan di Indonesia. Bab IV mengatur Hak dan Kewajiban Warga Negara, Orang Tua, Masyarakat, dan Pemerintah. Bab V berisi tentang Peserta Didik yang memuat satu pasal saja (pasal 12). Pasal ini mengatur hak dan kewajiban peserta didik termasuk peserta didik asing. Bab VI menjelaskan Jalur, Jenjang, dan Jenis Pendidikan. Bab ini terdiri dari dua puluh pasal (pasal 13-32) yang terbagi dalam sebelas bagian. Bab VII berisi tentang Bahasa Pengantar. Bab ini hanya berisi satu pasal saja, yakni pasal 33. Pada bab ini ditegaskan bahwa bahasa Indonesia merupakan bahasa pengantar dalam pendidikan nasional. Bab VIII berisi tentang ketentuan Wajib Belajar yang hanya terdiri dari satu pasal (pasal 34).

Bab IX tentang Standar Nasional Pendidikan, hanya ada satu pasal dalam bab ini, yakni pasal 35, pada pasal ini dinyatakan adanya delapan standar nasional, yaitu standar isi, standar proses, standar kompetensi lulusan, standar pendidik dan tenaga kependidikan, standar sarana dan prasarana, standar pengelolaan, standar 
pembiayaan, serta standar penilaian. Bab X berisi perihal Kurikulum. Bab ini memuat tiga pasal penting (pasal 36, 37, dan 38). Bab XI berisi tentang Pendidik dan Tenaga Pendidikan yang memuat enam pasal (pasal 39-44). Bab XII berisi tentang Sarana dan Prasarana Pendidikan yang hanya memuat satu pasal (pasal 45). Bab XIII tentang Pendanaan Pendidikan.

Bab XIV berisi tentang Pengelolaan Pendidikan. Bab XV berisi tentang Peran serta Masyarakat dalam Pendidikan. Bab XVI berisi tentang Evaluasi, Akreditasi, dan Sertifikasi. Bab XVII berisi tentang Pendirian Satuan Pendidikan yang memuat dua pasal (pasal 62 dan 63). Bab XVIII berisi tentang penyelenggaraan pendidikan oleh lembaga negara lain. Bab XIX berisi tentang Pengawasan. Bab XX berisi tentang Ketentuan Pidana terhadap pelanggaran penyelenggaraan pendidikan. Bab XXI berisi Ketentuan Peralihan. Bab XXII yang merupakan bab terakhir dalam undang- undang ini berisi tentang Ketentuan Penutup.

Dari aspek-aspek yang termuat dalam UU Sisdiknas 2003 seperti diuraikan di atas, jelaslah bahwa banyak kebijakan pendidikan baru yang dibuat dalam penyelenggaraan pendidikan nasional. Kebijakan-kebijakan di bidang pendidikan ini dibuat dalam rangka mengantisipasi perkembangan dan dinamika yang terjadi di tengah-tengah masyarakat seiring dan sejalan dengan dinamika dan perkembangan yang terjadi di dunia pada umumnya. Dan yang paling penting untuk ditegaskan di sini adalah bahwa kebijakan-kebijakan dalam penyelenggaraan pendidikan ini dibuat dalam rangka pencapaian tujuan pendidikan nasional seperti dirumuskan dalam UU Sisdiknas 2003 Pasal 3.

Kaitannya dengan kebijakan pendidikan juga tertera dalam Undang-Undang No. 32 Tahun 2004 tentang Pemerintahan Daerah ini merupakan kelanjutan dari Undang-Undang sebelumnya yang juga mengatur urusan tata pemerintahan daerah, yakni Undang-Undang No. 22 Tahun 1999 tentang Pemerintahan Daerah yang dinilai tidak sesuai dengan perkembangan keadaan, ketatanegaraan, dan tuntutan penyelenggaraan otonomi daerah sehingga perlu diganti. UndangUndang Pemerintahan Daerah 2004 ini terdiri dari 16 bab 240 pasal. Undangundang ini dikenal juga dengan undang-undang otonomi daerah karena UU ini 
berisi tentang penyerahan sejumlah wewenang yang semula menjadi urusan pemerintah pusat kepada pemerintah daerah, termasuk di dalamnya pengelolaan bidang pendidikan.

Tahun 2005 keluar Undang-Undang No. 14 tahun 2005 tentang Guru dan Dosen Undang-Undang ini lahir didasari tiga pertimbangan pokok, yaitu: 1) Bahwa pembangunan nasional dalam bidang pendidikan adalah upaya mencerdaskan kehidupan bangsa dan meningkatkan kualitas manusia Indonesia yang beriman, bertakwa, dan berakhlak mulia serta menguasai ilmu pengetahuan, teknologi, dan seni dalam mewujudkan masyarakat yang maju, adil, makmur, dan beradab berdasarkan Pancasila dan Undang-Undang Dasar Negara Republik Indonesia Tahun 1945; 2) Bahwa untuk menjamin perluasan dan pemerataan akses, peningkatan mutu dan relevansi, serta tata pemerintahan yang baik dan akuntabilitas pendidikan yang mampu menghadapi tantangan sesuai dengan tuntutan perubahan kehidupan lokal, nasional, dan global perlu dilakukan pemberdayaan dan peningkatan mutu guru dan dosen secara terencana, terarah, dan berkesinambungan; dan 3) Bahwa guru dan dosen mempunyai fungsi, peran, dan kedudukan yang sangat strategis dalam pembangunan nasional dalam bidang pendidikan sebagaimana dimaksud pada nomor 1) sehingga perlu dikembangkan sebagai profesi yang bermartabat; Pada tahun 2009 keluar lagi Undang-Undang Nomor 9 Tahun 2009 tentang Badan Hukum Pendidikan yang lahir sebagai kelanjutan sekaligus pelaksanaan dari ketentuan yang ada dalam UU Sisdiknas 2003, khususnya Pasal 53. Namun, sejak 1 April 2010 Undang-undang BHP tidak berlaku lagi karena telah dibatalkan oleh MK yang menilai UU BHP tidak selaras dengan UUD 1945 dan menimbulkan ketidakpastian hukum.

\section{Peraturan Pemerintah tentang Pendidikan sebagai Pelaksanaan Kebijakan Nasional di Bidang Pendidikan}

UU Sisdiknas 2003 secara umum sudah memberikan garis-garis besar atau prinsip-prinsip dasar dalam pelaksanaan pendidikan nasional. Hampir semua kebijakan pokok pendidikan nasional sudah termuat dalam UU tersebut. Namun, sudah pasti karena UU tersebut merupakan UU induk tentang sistem pendidikan nasional, maka sudah pasti ketentuan-ketentuan yang ada sangatlah umum dan 
perlu ketentuan-ketentuan yang lebih rinci yang sekaligus merupakan aturan pelaksanaan dari UU tersebut. Aturan pelaksanaan dari UU Sisdiknas 2003 ada yang berupa UU seperti yang sudah dipaparkan di atas dan ada juga yang berupa Peraturan Pemerintah (Marzuki, 2012). Di antara PP yang merupakan aturan pelaksanaan dari UU Sisdiknas 2003 adalah:

1. Peraturan Pemerintah No. 19 tahun 2005 tentang Standar Nasional Pendidikan,

2. Peraturan Pemerintah No. 23 tahun 2005 tentang Pengelolaan Keuangan Badan Layanan Umum,

3. Peraturan Pemerintah No. 55 tahun 2007 tentang Pendidikan Agama dan Pendidikan Keagamaan,

4. Peraturan Pemerintah No. 47 tahun 2008 tentang Wajib Belajar,

5. Peraturan Pemerintah No. 48 tahun 2008 tentang Pendanaan Pendidikan,

6. Peraturan Pemerintah No. 74 tahun 2008 tentang Guru,

7. Peraturan Pemerintah No. 37 tahun 2009 tentang Dosen,

8. Peraturan Pemerintah No. 41 tahun 2009 tentang Tunjangan Profesi Guru dan Dosen, Tunjangan Khusus Guru dan Dosen, serta Tunjangan Kehormatan Profesor,

9. Peraturan Pemerintah No. 17 tahun 2010 tentang Pengelolaan dan Penyelenggaraan Pendidikan, dan

10. Peraturan Pemerintah No. 66 tahun 2010 tentang Perubahan Atas Peraturan Pemerintah Nomor 17 Tahun 2010 tentang Pengelolaan dan Penyelenggaraan Pendidikan.

Di samping PP, aturan pelaksanaan dari berbagai kebijakan pendidikan yang tertuang dalam UU Sisdiknas 2003 juga dalam bentuk peraturan menteri pendidikan nasional (Permendiknas). Beberapa Permendiknas yang mengatur masalah kebijakan pendidikan adalah:

1. Permendiknas No. 22 tahun 2006 tentang Standar Isi untuk Satuan Pendidikan Dasar dan Menengah,

2. Permendiknas No. 23 tahun 2006 tentang Standar Kompetensi Lulusan untuk Satuan Pendidikan Dasar dan Menengah, 
3. Permendiknas No. 12 tahun 2007 tentang Standar Pengawas Sekolah,

4. Permendiknas No. 13 tahun 2007 tentang Standar Kepala Sekolah,

5. Permendiknas No. 16 tahun 2007 tentang Standar Kualifikasi Akademik dan Kompetensi Guru,

6. Permendiknas No. 19 tahun 2007 tentang Standar Pengelolaan Pendidikan oleh Satuan Pendidikan Dasar dan Menengah,

7. Permendiknas No. 20 tahun 2007 tentang Standar Penilaian Pendidikan,

8. Permendiknas No. 24 tahun 2007 tentang Standar Sarana dan Prasarana untuk Sekolah Dasar/Madrasah Ibtidaiyah (SD/MI), Sekolah Menengah Pertama/ Madrasah Tsanawiyah (SMP/MTs), dan Sekolah Menengah Atas/Madrasah Aliyah (SMA/MA),

9. Permendiknas No. 41 tahun 2007 tentang Standar Proses untuk Satuan Pendidikan Dasar dan Menengah,

10. Permendiknas No. 24 tahun 2008 tentang Standar Tenaga Administrasi Sekolah/Madrasah,

11. Permendiknas No. 25 tahun 2008 tentang Standar Tenaga Perpustakaan Sekolah/Madrasah,

12. Permendiknas No. 26 tahun 2008 tentang Standar Tenaga Laboratorium Sekolah/Madrasah,

13. Permendiknas No. 27 tahun 2008 Standar Kualifikasi Akademik dan Kompetensi Konselor,

14. Permendiknas No. 33 tahun 2008 tentang Standar Sarana dan Prasarana untuk Sekolah Dasar Luar Biasa (SDLB), Sekolah Menengah Pertama Luar Biasa (SMPLB), dan Sekolah Menengah Atas Luar Biasa (SMALB),

15. Permendiknas No. 40 tahun 2008 tentang Standar Sarana dan Prasarana untuk Sekolah Menengah Kejuruan/Madrasah Aliyah, Kejuruan (SMK/MAK),

16. Permendiknas No. 3 tahun 2009 tentang Petunjuk Teknis Pelaksanaan Dana Alokasi Khusus (DAK) bidang Pendidikan Tahun Anggaran 2009,

17. Permendiknas No. 10 tahun 2009 tentang Sertifikasi Bagi Guru Dalam Jabatan,

18. Permendiknas No. 47 tahun 2009 tentang Sertifikasi Pendidikan untuk Dosen, 
19. Permendiknas No. 69 tahun 2009 tentang Standar Biaya Operasi Nonpersonalia Tahun 2009 untuk Sekolah Dasar/Madrasah Ibtidaiyah (SD/MI), Sekolah Menengah Pertama/Madrasah Tsanawiyah (SMP/MTs), Sekolah Menengah Atas/Madrasah Aliyah (SMA/MA), Sekolah Menengah Kejuruan (SMK), Sekolah Dasar Luar Biasa (SDLB), Sekolah Menengah Pertama Luar Biasa (SMPLB), dan Sekolah Menengah Atas Luar Biasa (SMALB).

Kebijakan pendidikan yang diatur dalam perundang-undangan tersebut terkait dengan berbagai permasalahan pendidikan di Indonesia. Di antaranya adalah masalah-masalah Akreditasi Nasional bidang Pendidikan, Ujian Nasional dan Ujian Akhir Sekolah Berstandar Nasional, Kebijakan Buku Nasional, Kurikulum Berbasis Kompetensi (KBK), Kurikulum Tingkat Satuan Pendidikan (KTSP), Standarisasi Pendidikan Nasional, Sekolah Standar Nasional (SSN), Rintisan Sekolah Bertaraf Internasional (RSBI), Sekolah Gratis, Perguruan Tinggi sebagai Badan Hukum Pendidikan, Kebijakan Guru Bantu, Sertifikasi Guru dan Dosen, Tunjangan Profesi bagi Guru dan Dosen, Pengarusutamaan Gender dalam Bidang Pendidikan, dan Pencegahan dan Penanggulangan Plagiasi.

\section{Kebijakan Nasional Pendidikan dan Sumbangannya dalam Perpolitikan Nasional}

Berbagai kebijakan pokok yang terdapat dalam UU Sisdiknas 2003 dalam implementasinya memunculkan kebijakan-kebijakan pendidikan lain yang tidak bisa diungkap satu per satu di sini. Sebagai contoh, kebijakan wajib belajar sembilan tahun berkonsekuensi adanya kebijakan sekolah gratis bagi peserta didik yang mengikuti program wajib belajar sembilan tahun di Sekolah Dasar (SD) dan Sekolah Menengah Pertama (SMP). Kebijakan sekolah gratis banyak dijadikan jargon dalam kampanye dan tujuan-tujuan politis. Tidak sedikit di antara para calon kepala daerah baik di tingkat kabupaten/kota maupun di tingkat provinsi yang menawarkan sekolah gratis di daerahnya jika mereka dipercaya menjadi kepala daerah (Marzuki, 2012).

Bersamaan dengan kebijakan wajib belajar ini pemerintah menganggarkan biaya yang cukup besar untuk mendanai terlaksananya kebijakan wajib belajar 
dan sekolah gratis. Kebijakan dalam bidang pendanaan pendidikan di sini kemudian dikenal dengan istilah biaya operasional sekolah (BOS). Dengan dana BOS inilah sekolah dapat menjalankan seluruh kegiatan akademik yang ada di sekolah. Dalam implementasinya, kebijakan BOS ini berjalan dengan baik, meskipun juga ada kelemahan dan kekurangannya.

Secara umum dapat dianalisis bahwa kebijakan pendidikan di Indonesia, terutama yang didasarkan pada Undang-Undang Sisdiknas 2003 dan peraturan perundang-undangan di bawahnya (PP dan Permendiknas) diarahkan untuk mencapai hal-hal sebagai berikut:

a. Meningkatkan profesionalisme tenaga pendidik (guru dan dosen) dengan memberikan fasilitas yang memadai baik sarana dan prasarana maupun kesempatan untuk melanjutkan pendidikan pada jenjang yang lebih tinggi demi peningkatan kualitas mereka. Kebijakan ini juga disertai dengan kebijakan pemberian tunjangan profesi bagi guru dan dosen yang cukup memberikan tambahan motivasi dalam melaksanakan tugas mereka serta memberikan harapan besar untuk menambah kesejahteraan mereka.

b. Mengupayakan perluasan dan pemerataan kesempatan memperoleh pendidikan yang bermutu tinggi bagi seluruh rakyat Indonesia menuju terciptanya manusia Indonesia berkualitas tinggi dengan peningkatan anggaran pendidikan secara berarti. Alokasi dana pendidikan 20\% dari APBN dan APBD merupakan rekor tertinggi selama ini;

c. Meningkatkan kualitas lembaga pendidikan yang diselenggarakan baik oleh masyarakat maupun pemerintah untuk memantapkan sistem pendidikan yang efektif dan efisien dalam menghadapi perkembangan ilmu pengetahuan, teknologi, dan seni serta dalam rangka menyongsong globalisasi yang menghadapkan pendidikan nasional dengan pendidikan di negara-negara lain;

d. Meningkatkan kemampuan akademik dan profesional serta meningkatkan jaminan kesejahteraan tenaga kependidikan sehingga tenaga pendidik mampu berfungsi secara optimal terutama dalam peningkatan pendidikan watak dan budi pekerti agar dapat mengembalikan wibawa lembaga dan tenaga kependidikan; 
e. Meningkatkan mutu dan kualitas lembaga pendidikan serta pendidik dan tenaga pendidikannya beserta sarana dan prasarananya melalui penetapan berbagai standar pendidikan;

f. Melakukan pembaruan dan pemantapan sistem pendidikan nasional berdasarkan prinsip desentralisasi, otonomi keilmuan dan manajemen;

\section{Problema dan solusi dalam implementasi kebijakan nasional bidang pendidikan}

Dalam rentang tahun 2003 hingga 2010 sudah banyak kebijakan pendidikan yang muncul mewarnai pelaksanaan sistem pendidikan nasional. Secara umum kebijakan-kebijakan ini sudah dipaparkan di atas dengan berbagai perangkat hukum yang menyertainya (Marzuki, 2012). Jika dicermati lebih detail, sebenarnya pelaksanaan berbagai kebijakan pendidikan yang sekaligus merupakan politik pendidikan nasional masih menyisakan berbagai problem yang menarik untuk dikaji. Di antara problem tersebut dipaparkan sebagai berikut:

a. Praktik pelaksanaan wajib belajar yang kemudian memunculkan jargon "Sekolah Gratis" belum semuanya ditanggapi dengan baik dan diterima secara penuh oleh semua warga sekolah. Masih ada pihak-pihak yang merasa dirugikan dengan adanya kebijakan ini, sehingga melakukan hal-hal yang merugikan sekolah, yang akhirnya merugikan siswa dan orang tua siswa. Ketika terjadi pengetatan dana dengan dalih kebijakan "sekolah gratis", program-program yang sudah berjalan dengan baik mulai sedikit demi sedikit terabaikan. Peran kepala sekolah menjadi sangat penting untuk membawa sekolah tetap eksis dengan program-program sekolah yang mendukung suksesnya pendidikan dan pengajaran di sekolah, sehingga siswa tetap dapat menikmati semua program sekolah dan mendapatkan hasil yang maksimal sebagaimana mestinya;

b. Sebagai konsekuensi adanya "sekolah gratis" bagi sekolah negeri menjadikan sebagian dari sekolah-sekolah yang dikelola oleh swasta menjadi "mati". Namun demikian, tidak sedikit juga sekolah-sekolah swasta yang mampu bertahan bahkan terus berkembang dengan tawaran-tawaran program khusus sekolah yang dapat menarik siswa dan orang tua siswa mengikuti pendidikan di 
sana. Inovasi dan kreativitas pimpinan sekolah (kepala sekolah) sangat dituntut untuk tetap mempertahankan sekolahnya eksis di tengah-tengah masyarakat. Sekolah-sekolah swasta ini harus memiliki keunggulan-keunggulan agar tetap bisa bertahan dan terus diminati masyarakat;

c. Program sertifikasi guru dan dosen juga menyisakan problem yang tidak sedikit. Bagi guru program ini mengakibatkan kesenjangan yang jelas antara guru yang sudah mendapatkan sertifikasi dengan yang belum. Di samping karena masalah gaji yang berbeda, ternyata prestis di antara guru yang profesional dengan yang belum juga berbeda. Akibatnya adalah terjadi kinerja yang kurang maksimal di kalangan para guru yang belum profesional dengan alasan kurangnya gaji yang diterima dibanding dengan guru yang sudah profesional. Hal yang sama juga terjadi di kalangan dosen. Bahkan problem besar di kalangan dosen terkait dengan kebijakan ini adalah banyaknya dosen yang profesional ini tidak mau melanjutkan studi ke jenjang berikutnya (Strata 3/program doktor) karena jika melanjutkan studi tunjangan sertifikasinya akan dihentikan. Namun demikian, tidak sedikit juga dosen yang mengambil keputusan tetap harus melanjutkan studi karena ada harapan untuk meraih kesejahteraan yang lebih baik lagi, yakni ketika pada akhirnya memperoleh jabatan guru besar yang mendapatkan tunjangan kehormatan di samping juga mendapatkan tunjangan sertifikasi. Diperlukan teman sejawat dan utamanya dari pimpinan lembaga untuk memotivasi lanjut studi. Banyak fasilitas yang dapat diakses di luar personal seperti Pemerintah dan lembaga-lembaga tertentu yang dalam hal ini menyediakan fasilitas beasiswa lanjut studi;

d. Kebijakan adanya standardisasi pendidikan juga menyisakan beberapa problem, terutama bagi sekolah-sekolah swasta. Tidak banyak sekolah swasta yang mampu membenahi kelembagaannya menjadi sekolah yang berstandar nasional. Kebijakan ini memang menjadi tantangan tersendiri bagi para pengelola sekolah, sebab jika tidak bisa mewujudkan sekolah yang berstandar akan berakibat berkurangnya minat masyarakat bersekolah di sekolah tersebut. Jika ini terjadi akan mengurangi pemasukan dana yang menjadi tulang punggung sekolah untuk menjalankan program-program sekolahnya. Solusi 
terbaik adalah peran serta yayasan yang menaungi lembaga pendidikan swasta untuk mengadakan evaluasi dan pembinaan seperti sosialisasi dan seminar pendidikan, sehingga manajemen terkontrol dengan baik. Selain itu diperlukan juga proaktif dari pimpinan lembaga terhadap perubahan yang terjadi di lingkungan lembaga. Adakan studi banding ke lembaga pendidikan lain yang sudah berstandar sehingga bisa ditiru demi eksistensi keberadaan lembaga sekolah;

e. Kebijakan pendidikan yang hingga sekarang masih menimbulkan perbedaan persepsi di tengah-tengah masyarakat adalah kebijakan ujian nasional. Banyak masyarakat yang menghendaki kebijakan ini ditinjau ulang, mengingat adanya praktik-praktik yang tidak dikehendaki terkait dengan kebijakan ini. Hampir setiap tahun pelaksanaan ujian nasional menyisakan problem terutama terjadinya kebocoran soal dan kecurangan dalam pelaksanaannya. Belum lagi cost yang dikeluarkan untuk ujian nasional ini cukup tinggi. Solusi utamanya ialah peninjauan ulang terhadap kebijakan yang sudah berjalan. Hal ini dipandang perlu, terutama oleh para pengelola pendidikan nasional (pemerintah), dalam rangka menjamin terwujudnya pendidikan yang berkualitas. Variasi kualitas sekolah yang ada belum memungkinkan untuk menyerahkan penilaian kompetensi kepada sekolah. Maka dalam mata pelajaran tertentu masih dirasa perlu distandarkan penilaiannya secara nasional, sehingga ada jaminan yang lebih terpercaya, dibandingkan jika dilaksanakan oleh sekolah-sekolah yang bervariasi mutunya. Yang harus diperhatikan di sini sebenarnya bukan masalah kebijakan ujian nasional ini dalam arti pelaksanaannya saja, tetapi bagaimana pemerintah juga memfasilitasi sekolah dan masyarakat agar benar-benar siap dan bisa mengikuti ujian nasional dengan baik dan adil di tengah perbedaan yang terjadi di masyarakat yang tersebar di berbagai daerah yang situasi dan kondisinya juga berbeda-beda. Jika ini dilakukan, barangkali problem-problem yang selama ini ada akan bisa dieliminasi.

Sebenarnya masih banyak permasalahan pendidikan nasional yang masih membutuhkan kajian lebih mendalam untuk bisa dicari pemecahannya. Secara 
bertahap pendidikan nasional diupayakan untuk terus maju agar sejajar dan seimbang dengan pendidikan di negara-negara lain terutama di kawasan Asia Tenggara seperti Malaysia, Singapura, dan Thailand. Untuk mendukung terwujudnya pendidikan yang baik yang sangat dibutuhkan adalah kestabilan politik dan ekonomi nasional. Jika tidak, akan sulit terwujud pendidikan nasional yang kita dambakan bersama.

\section{Simpulan}

Kesimpulan yang dapat diambil dari uraian yang panjang tersebut adalah sebagai berikut: Pertama, Ada beberapa kebijakan pendidikan nasional khususnya yang tertuang dalam Undang-Undang Sisdiknas 2003, Kedua, Permasalahan yang muncul seiring dengan pemberlakuan berbagai kebijakan nasional di bidang pendidikan di Indonesia juga cukup banyak. Di antara permasalahan tersebut adalah terkait dengan kebijakan-kebijakan: a. Wajib belajar dan pendanaan pendidikan yang praktiknya masih beragam; b. Sertifikasi guru dan dosen yang juga memunculkan berbagai problem seperti kesenjangan dan praktik-praktik yang merugikan lembaga pendidikan; c. Standardisasi pendidikan juga berakibat adanya kesenjangan antar sekolah yang satu dengan yang lain; d. Ujian nasional yang masih terus menyisakan permasalahan; e. Pelaksanaan Pendidikan Agama dan Pendidikan Keagamaan yang belum tertata dengan baik. Berbagai pemecahan sudah ditempuh untuk menyelesaikan problem-problem tersebut. Karena perbedaan situasi dan kondisi di masing-masing daerah tempat pelaksanaan berbagai kebijakan pendidikan, maka masih banyak problem yang belum teratasi dengan tuntas dan masih terus diupayakan. Namun, sudah banyak pula problem yang teratasi dengan baik berkat dukungan dari berbagai pihak terkait. 


\section{REFERENSI:}

Assegaf, A. R. (2005). Politik Pendidikan Nasional: Pergeseran Kebijakan Pendidikan Agama Islam dari Proklamasi ke Reformasi. Yogyakarta: Kurnia Kalam.

Husaini Usman. (2006). Manajemen: Teori, Praktik, dan Riset Pendidikan. Jakarta: Bumi Aksara.

Marzuki. (2012). POLITIK PENDIDIKAN NASIONAL DALAM BINGKAI UNDANG-UNDANG SISTEM PENDIDIKAN NASIONAL, 17(2).

Peraturan Pemerintah No. 19 tahun 2005 tentang Standar Nasional Pendidikan.

Peraturan Pemerintah No. 55 tahun 2007 tentang Pendidikan Agama dan Pendidikan Keagamaan.

Peraturan Pemerintah No. 47 tahun 2008 tentang Wajib Belajar.

Peraturan Pemerintah No. 48 tahun 2008 tentang Pendanaan Pendidikan.

Peraturan Pemerintah No. 74 tahun 2008 tentang Guru. Peraturan Pemerintah No. 37 tahun 2009 tentang Dosen.

Peraturan Pemerintah Nomor 17 Tahun 2010 tentang Pengelolaan dan Penyelenggaraan Pendidikan.

Peraturan Pemerintah Nomor 66 tahun 2010 tentang Perubahan Atas Peraturan Pemerintah Nomor 17 Tahun 2010 tentang Pengelolaan dan Penyelenggaraan Pendidikan.

Tilaar, H. A. . (2009). Kekuasaan dan Pendidikan: Manajemen Pendidikan Nasional dalam Pusaran Kekuasaan. Jakarta: Rineka Cipta.

Undang-Undang No. 20 tahun 2003 tentang Sistem Pendidikan Nasional.

Undang-Undang No. 32 tahun 2004 tentang Pemerintah Daerah. Undang-Undang No. 14 tahun 2005 tentang Guru dan Dosen. 